42. Gregersen MI 1944 A practical method for the determination of blood volume with the dye T-1824. J Lab Clin Med 29:1266-1286

43. Nitshe GA Jr, Cohen PP 1947 Simplified determination of blood volume. Am $J$ Clin Pathol 17:239-243

44. Mollison PL, Veall N, Cutbush M 1950 Red cell and plasma volume in newborn infants. Arch Dis Child 25:242-253

45. Sisson TRC, Lund CJ, Whalen LE, Telek A 1959 The blood volume of infants: I: The full-term infant in the first year of life. J Pediatr 55:163-179

46. Low JA, Kerr ND, Cochon AR 1963 Plasma and blood volume of the normal newborn infant and patterns of adjustment in initial 24 hours of the neonatal period. Am J Obstet Gynecol 86:886-892

47. Cassady G 1966 Plasma volume studies in low birth weight infants. Pediatrics
38:1020-1027

48. Brans YW, Milstead RR, Bailey PE, Cassady G 1974 Blood-volume estimates in Coombs-test-positive infant. N Engl J Med 290:1450-1452

49. Barr PA, Bailey PE, Sumner J, Cassady G 1977 Relation between arterial blood pressure and blood volume and effect of infused albumin in sick preterm infants. Pediatrics 60:282-289

50. Ingomar CJ, Klebe JG, Baekgaard P 1973 The transcapillary escape rate of T1824 in healthy newborn infants: the influence of the placental transfusion. Acta Paediatr Scand 62:617-620

51. Phibbs RH, Johnson P, Tooley WH 1974 Cardiorespiratory status of erythroblastotic newborn infants. II. Blood volume, hematocrit, and serum albumin concentration in relation to hydrops fetalis. Pediatrics 53:13-23

\title{
Announcement
}

\section{CHILD HEALTHCARE FIELD RESEARCH IN BRAZIL}

Medical professionals, especially nurse and M.D. medical anthropologists, are needed to participate in field research focusing on child healthcare in Brazil.

The University Research Expeditions Program, now in its 13th year, makes it possible for interested members of the public to spend 2 to $3 \mathrm{wk}$ as active members of a University of California research team. No previous experience is necessary for most expeditions.

The expedition teams, which usually include 8 to 10 participants, leave for destinations all over the world throughout the year, although most are concentrated in summer and winter. Participants in all UREP expeditions make a tax-deductible contribution to cover their expenses and help make the research possible.

For a free catalog and applications, contact desk K03, University Research Expeditions Program, University of California, Berkeley, CA 94720. Phone: (415) 642-6586. 